\title{
LABOUR PRACTICES AND ARRANGEMENT IN THE RAJBANSHI SOCIETY
}

Keshav Kumar SHRESTHA

\section{ABSTRACT}

Rajbanshis are indigenous people and have their own labour practices and labour arrangement system. Traditionally, they have divided their work loads according to type of works by sex and age. Like other communities, females have to bear double responsibility - to look after their homes as well as agriculture. Hence they are occupying important part of the Rajbanshi community from the labour arrangement perspective. The Rajbanshi community comprises of caste and sub-caste system based on labour practices. But the widow labour system which was present in the community has now been disappeared.

KEY WORDS: Division of work, Labour system, Labour distribution, Rajbanshi society

\section{BACKGROUND}

Rajbanshi is racially a mix group (known by indigenous people) and entered Nepal in around 1515 AD from Koch or Koche Bihar or Asam of India. Socio-culturally they are more distinct than that of other indigenous community Satar and Tharu of Nepal. Their culture has been rooted to the abundant land resource. The economic system has positively and negatively related to the overall aspect of their lives where economic system is the foundation of the community. It is primarily related to the production of goods and services, governance and religious system.

Indigenous Rajbanshi people have also been dependent on farming since time immemorial. Their primary occupation is agriculture, traditionally growing paddy and animal husbandry. Nowadays those who possessed land, they are practicing crop diversification and even in the micro-level commercial farming of potato, cabbage, cauliflower, eggplant etc. Once they controlled vast stretch of farm land of Jhapa and 
Labour practices...... Shrestha

Morang districts. During the democratic movement of 1950, Limbus of Eastern hills had forcefully driven away the Bramin, Chhetri and other non-Limbus because of land issue. The hill migration accelerated then. It followed after malaria eradication program. Gradually, in some place these immigrants cleared the forest land and settled there. By and by the hill people have gradually taken away the Tarai indigenous people such as Rajbanshi, Satar etc. Even it has happened in the hill areas between Brahmin/Chhetri and Limbus. Hindu tribal relation has been mentioned in the Lionel Caplan book entitled 'Land and Social Change in East Nepal (1970/2000). By and large, these Rajbanshis are humble people with modest aspiration. They content themselves with what they possess. They are hardworking and helpful as well. However, they are not thrifty one. Large chunk of their income is spent on food, drink, funfair and entertaining their guests. Thus, they fall on the debt snare of money lenders or pawn-brokers on mortgaging their land. In addition, these land hungry Nepali speaking people who are linked with the state power and authority by language and culture, gradually snatch these people's land in one or other pretext.

Since the advent of Indian Marwadi and hill migrants their economic condition gradually being weaker and weaker due to selling out land. The pull and push factors of monetization of economy they started taking loan to fulfill their socio-cultural consumption needs. The land reform programme of 1964 also aggravated their situation since most of the hill people control the bureaucracy. Many landlord Rajbanshi turned into small land-owners and some of them became landless within a generation or two. Like Tharu people, Rajbanshi used to live in joint or extended family. The land reform programme 1964, and other factors compelled their family disorganization and they started to practice land fragmentation being neuclearization of their family. As a process of neuclearization of family, they started residing their own respective house or hut. Consequently, division of land among the brothers and sons also played a key role to turn them as small land owners, peasant farmers and the landless. Many of them have been practicing farming like their indigenous counterparts of Satar, Meche, Dhimal, etc. After they have lost control over the land resource, they have been compelled to do any type of jobs available. 
The Rajbanshi, who are mainly residing in Jhapa and Morang districts, have rarely left their place for third country employment. However, these districts are bordered with India and there is no restriction or any formality to cross border. Many of them are found in Indian cities of Kolkata, Gujrat, Punjab and elsewhere as agriculture workers as well as odd jobs available in the Indian cities as seasonal workers to earn their living. Of late, those who can save a little try to invest on cattle trade, but many others spend all the money on food and clothes.

Rajbanshi people are very skillful in making wooden ploughs, cattle yoke, constructing and repairing wooden and thatched houses or huts. The alternative income sources of the (sample) households in the study area consist of town odd jobs (Shrestha, 2008). Competitions in the job market, transport facilities to go here and there, interactions with various ethnic people, and different alternative sources of income have huge impact on their livelihood. All these factors have brought changes in their traditional lifestyles and economic structures of the Rajbanshi people.

Beside agriculture and wage labourers, a few Rajbanshis are found working as liaison workers as self-employers in land revenue and land reform offices. They help prepare documents and play the role of middle person between the officials and general public. Some are working in tractor driving, cycle repairing, wall painting, rickshaw pulling, carpentry, construction workers, tea plantation workers, etc. A few educated Rajbanshi youths are working as teachers, officials, politicians, etc. Animal husbandry, poultry farming and milk businesses are other alternative sources. They are fond of keeping duck for their consumption and for market.

Despite living in the $21^{\text {st }}$ century, they still keep old belief of witchcraft, ghosts, spirits, and superstitions. This has encouraged a few Rajbanshi people to work as witchdoctors for the treatment of the human illness and diseases as their occupation known by Gosain, Dhami, and Ojha. These people recite some mantras (holy words) and use some traditional herbal medicines to cure physical and psychological illnesses and diseases. They are believed to have spiritual and divine power to treat them. The clients voluntarily offer some money and food 
for witchdoctors. Even today, one or two families of such witchdoctors are found in every village and they are ready to help the patients round the clock. They are acting as emergency treatment providers. This practice is still continuing as a compulsion or an alternative. More or less similar such practices have been found in Western Tarai districts (Prasain, 2007).They also started to go to the health institutions, clinics and pharmacy to seek modern health services after visiting the traditional inhaler.

The article is based on the fieldwork of the academic research carried out in Jhapa district of Eastern Nepal during 2003/04. The main objective of this article is to document the different labour practices and labour arrangement system of Rajbanshi people. The survey covered two Village Development Committee Gaurigunj and Banyan) and one municipality (Mechi Nagar Nagarpalika). One hundred households were selected from the sampled VDCs and municipality using systematic random sampling. From each household one well informed family member was interviewed with the help of well structured checklist. Besides the household information, more information were obtained from the key-informant interview and observation of the selected households in particular and community in general.

\section{DIVISION OF WORK IN THE FAMILY}

Loosing their land, of late, Rajbanshi of Jhapa district and especially in the study area mostly depend on wage earning. Without land, they have little choices to earn a living. So whatever work is available they are compelled to accept. Despite the changing context, women have to bear double responsibilities of caring of young and old and work outside the four walls of their houses. Male authority is still prevalent in their socio-cultural life. But overall responsibility of supporting of family rests on the father. When father dies the responsibility automatically shifts to elder brother. Similarly, the eldest woman of the family takes leadership of the household work. As the family structure is patriarchal, it is the male member who takes all kinds of decisions in the family matter. Gradually, things are different and noticeable changes in such decision-making process have been evolving. Nonetheless there are a few joint families of Rajhanshi, and the traditional types of decision- 
making practices are still prevalent in those families among the study households.

The aggregate labour practice or the total labour culture among the Rajbanshi community can be divided into three categories - child labour, women labour and men labour. It is relevant to shed light furthermore in the following sections.

\section{CHILDREN'S WORK}

Working children cover the age group from 5 to 13 . Children above 5 years usually go to school but they are busy at household activities in their spare time and holidays. Normally, boys of 5 to 6 years help the family by grazing oxen, cows and goats whereas girls look after their younger siblings at home to make free for their adult or working age family members. When girls become 8 or 9 years old, they help the family members by washing dishes, bringing water from wells, making dung-sticks, etc. Girls of 10 or 11 years help their mothers and sisterin-laws in cooking. When they reach 12 or 13 years, they become able to take adult members responsibilities like boiling rice, husking rice, preparing beaten rice, and roasted rice (Murai), irrigating vegetable gardens, taking care of their fowls.

Not only the children do the household chores like cleaning the house, washing clothes etc, they also help their parents in planting rice and other farm work. The children of 9 or 10 years keep themselves busy cutting grass, and taking meals to the field for working adults. During rice planting season they also do collecting rice saplings, and putting it on the different plots of land, making ready to plant them. Male children of 12 or 13 years plough the field, plant rice, harvest rice, drive oxen carts, make the plots ready for planting etc. They work like the adult members. They are also interested in and skilled at fishing. The children of this age group are ready to learn every skill. They can repair their houses; make thatched roofs and bamboo walls. In this way, the children are fully involved in rural agricultural life. They are also going to school at the same time. Nowadays the awareness of Rajbanshi people has increased on sending their children to school 
Labour practices...... Shrestha

but they want their children to help them in their occupation as well. However, they do not stop their children at home during school time.

\section{WOMEN'S WORK}

There are two fold major tasks of the Rajbanshi women, i.e., they are busy at household activities from early morning to the late night caring young and old members. In addition, they have to participate in farming work and to run small family business (trade). It is their duty to go to market to buy and sell their products. They are responsible for replenishing rice, pulses, vegetables, salt, oil etc whatever they need in the kitchen. It is the women's role to look after children and serve guests at home. They clean inside and outside the house and the cow shed early in the morning. They also have to prepare tea snacks, food and take to the field for the working members in the field. Moreover, they prepare beaten and roasted rice for their family and for sale from early morning to late night. Women decorate their mud-wall by depicting murals peacocks, birds, horse, etc.

As women are responsible for kitchen, they have to manage kitchen. They go to hatiya (local market) by carrying rice, vegetables, yoghourt, beaten rice, roasted rice, fruits etc whatever they produce at home and sell them there. Running small businesses like selling grains and fruits and buying necessary kitchen things is the duty of Rajbanshi women. They are responsible for buying things of daily needs like salt, cooking oil, kerosene oil, tea dust, sweets for children at the market place. They keep ducks, chickens, goats and pigeons for economic support. They also save time for weaving clothes, bed sheets, jute mats etc. Looking after cows, feeding and milking them are also the women's jobs. They also prepare fuels for coking from rice husk, jute sticks, and cow-dung (Chipri).

However, it is the male members to decide on bigger transactions like buying and selling expensive clothes, land, houses, cattle etc. Male member rarely take suggestions from female members for making these decisions. Thus, the Rajbanshi women seem empowered in their homes and play an important role to run the household. Similarly, the old women look after homes and children, help with the kitchen work, 
and issue orders and trained the younger members of the tricks of the trade. Nowadays, education and modernization have brought slight changes in these traditional socio-cultural practices. They have also started doing small businesses, wage earning, running tea stalls and Betel nut (Supari) shops, etc.

\section{MEN'S WORK}

Traditionally man takes the major economic responsibility of the Rajbanshi households. As they depend on agriculture, so they have to plough the field, sow seeds in time, plant and harvest in time, prepare rice saplings, work in the muddy field, weed the plants and look after the whole crops. During planting and harvesting seasons, the villagers help each others. They keep themselves busy all the year round growing crops and vegetables. They collect grass for cattle. They feed and graze the cattle. They take the cattle to rivers and ponds where they drink water. They are responsible for putting manure in the fields and irrigating the land. They also collect firewood and make jute ropes and make hammock type of bed in the spare time. In winter, collecting, storing and piling up hay also come under the male responsibility.

They make bamboo stools, repair houses, transport goods by bull-cart, etc to generate income. Men also run small businesses. A few men are involved in government services, teaching professions and political parties. Mostly it is men who participate in marriage, parties, feasts, and other social and religious ceremonies. It is also men who receive and talk with guests. They are responsible for social and economic activities. In this way in joint families, father figure manages and controls the family labour arrangement. They also provide guidelines and work assignment to the family members and are responsible for continuity and maintaining the social relations as well.

\section{TYPES OF LABOUR ARRANGEMENT SYSTEM PREVALENT IN RAJBANSHI COMMUNITY}

Because of the macro process of change, the traditional labour arrangement system in the Rajbanshi family has been changing. The traditional boundary of work culture between woman and man has 
Labour practices...... Shrestha

becoming seamless. Traditional division of labour between both the sexes has been vanishing. Men lend their hands to the work domain of women. Men and women do not only depend on farming but also go out for finding jobs in factories, tea plantation to run businesses, etc. Among others, they have their traditional system of labour arrangement or practices. Let us discuss them in brief.

\section{DAGUWA AND DHANJIYA LABOUR}

Daguwa labour arrangement system is common in Rajbanshi society. A Rajbanshi man lives in the house of the widow as her husband, taking every responsibility of the family is known as Daguwa labour arrangement system. A Daguwa ploughs the field, grows crops, builds houses and takes every responsibility. However, he cannot take any wages and owns any property except sexual gratification from the widow. He cannot have any right to possess property, either. He works like a socially bonded worker. Although the Daguwa has the position of a husband, he has no authority in social and economic activities.

Dhanjiya labour is related to marriage system in the Rajbanshi society. In some families, a marriageable boy goes to live in the girl's house as a son-in-law but in a form of bonded worker. It is like the inceptional Kamaiya system Tharu of western Nepal. To become a real son-in-law, the boy has to work hard to make the girl's parents happy. If the girl's parents are happy, they will marry their daughter to the boy after a few years. Nowadays the system of Dhanjiya labour is rarely found in practice and it has nearly disappeared.

The other forms of labour practices are equally important among the Rajbanshi community. These are mainly- haliya, parma, and hauli systems.

\section{HALIYA SYSTEM}

In Rajbanshi society, the Haliya system is one of the sources of income for livelihood. Rajbanshi men go to live and work in other people's houses as a hali (ploughman). In the study zones, some Rajbanshi youths are found as hali in the houses of the people from the hills. The people of hilly origin are also found working as hali in other people's 
houses but the haliya system found in the study clusters of Jhapa is different from western Tarai haliya system (Gautam and Prasain, 2006).

Some of the Rajbanshi youths are working as hali in Rajbanshi and other societies. A hali is not expected to work as a servant to do household chores but he does other activities related to agriculture work. A hali is responsible for ploughing, planting, reaping and harvesting. Generally a hali has a contract period of one year. They are paid $4 / 5$ thousand rupees for the period. Sometimes the contract is made between the hali and the land-owner for the planting season for $4 / 5$ months only. During the planting season, normally the summer season, the hali is paid one thousand rupees a month. The hali is given residence, clothes, and food besides monthly or annual payment. The hali is duly given food (khaja) between the meals. Two sets of clothes with a set of summer dress are given. If the hali is sick, the land-owner has to provide treatment. The haliya system is still in practice in the society. Nowadays most of the land-owners are small land-owners who do not need to hire any workers in contract labour. But in the planting, reaping and harvesting seasons, they hire workers on daily wages.

\section{PARMA (LABOUR EXCHANGE SYSTEM)}

Before the monetization of the village economy, labour exchange system is prevalent in any geo-physical settings. Parma (labour exchange system) is common in the Rajbanshi society as well. It has been evolved in the time of labour shortage for agricultural, house construction as well as to fulfill other social labour requirements. When people have a lot of work which cannot be done by the family members themselves, they ask the villagers to help them. Help taken from others reciprocal labour exchange system, parma cannot be paid in money. It is similar to maijery, a collective parma system common in the Magar society. Parma is exchanged individually and collectively. The Rajbanshi generously help one another when more labour is needed for their work. The system is more common in the families which have bigger plots of land, where the labour of the concerned families is not enough. However, those who are small land-owners do not need parma. Nowadays, the parma system is gradually disappearing due to 
Labour practices...... Shrestha

the availability of cash and seasonal Indian labours. Thus, when more labours are needed, people hire wage workers.

\section{HAULI}

Hauli labour arrangement system is different from that of Parma system. When seasonal time is getting out of hand and more labour is needed especially for planting, harvesting, house building, etc neighbors are called for help. This system of helping each other in times of need is called hauli. This type of helping system is also found in different communities in the eastern Tarai. Bethi labour arrangement for rice planting is more or less equivalent to the hauli system of Tarai. The hauli labour arrangement is common in Dhimal community. The hauli system is popular because bigger tasks can be done soon at a time (Dahal, 2036 BS:56)

It is different from that of parma labour arrange system, because nobody has to pay back cash or kind in lieu of labour contribution. Those who contribute labour as hauli are given luxurious foods such as daal, fish, mutton, chicken curry more than one, bhat, yoghourt, beaten rice, roasted rice, tea and snacks. The hauli system was more popular when there was less density of population and no alternative way of getting helped. In this system they mutually help one another and save money on the one hand, and on the other, this helps manage the collective labour in the village. It has social cohesion function as well.

Any villager can call for hauli. There is no discrimination between the rich and prestigious and the poor and small land-owners to call for the hauli. The hauli system has been established as an important social emotional system in the Rajbanshi family. This has helped build and manage a cooperative notion of society. Women members generally do not participate in the hauli labour system, though there is no hard and fast rule about this. Normally, the head of the family takes part in the hauli, and they are generally men. The rich family sometimes hires a worker as a representative to be sent to the hauli for manual work but during the feast the head of the household also takes part. It is a traditional system which is respected in the society. It is also a 
socially binding labour arrangement system. Society takes it otherwise if someone does not participate. However, it does not fulfill the daily demand of labour, although, it helps to do bigger and important tasks in a short time.

Nowadays popularity of the hauli system is declining gradually because cash economy and modernization dominate their socio-cultural and economic life. The other side of the reason is that it is really difficult for a small family to manage a big feast for all the hauli participants and feeding so many people is very expensive due to rapid hike in market price. In this way, the traditional agriculture labour arrangement system has been rapidely changing over time. However, the hauli is still in practice partly in some of the rural areas of Gauriganj and Baniyani villages of Jhapa district. The system has totally disappeared in the Mechi municipality due to modernization and evolving nature of real estate business.

In addition to the said labour arrangement system, there exist castebased hierarchies of distribution among the Rajbanshi community. They used to do caste based works. The caste-based works can be succinctly dealt with subsequent paragraphs.

\section{CASTE-BASED LABOUR DISTRIBUTION}

The Rajbanshi community comprises of various castes such as, Mali, Kwali, Gangai, Thakur, Hadi, Gwala, etc. The division of labour on the basis of castes is described below:

a. Mali: Malis decorate bride and bridegrooms at marriages and prepare special wedding crowns for them. It is the most important caste of Rajbanshi community. It is a work of beautician in the exotic modern lexicon.

b. Kwali: Kwalis perform singing and dancing programmes from door to door and collect grains, and money in the months of March and April every year. During this season, the Kwalis beautifully sing hymns for the protection of cattle. The Kwali is one of the sub-castes of the Rajbanshi community. The Kwalis play the Kartal, a musical instrument for the protection of all the cattle in the village, visiting 
door to door and collecting money and grains. This custom is similar to the cone playing (blowing Feri custom) at night from door to door by Sanyasi (Jogi) in the hilly people's community. The Sanyasi visits every house playing the cone (Feri) for the protection of households from evil spirits at night every year. In the morning they revisit the households for collecting (dan, i.e., offering) money, turmeric, salt, black-bean, mustard oil, etc whatever they are offered. This traditional custom of the Kwali community still exists in the Rajbanshi society. And it was more important when Rajbanshi people used to keep more cattle. Nowadays it is becoming less popular along with the decreasing number of cattle in the households. The Kwalis are found involved in other occupations as well rather than begging by singing hymns. The vestige of this type of labour practice is still existed.

c. Gangai: Generally Gangai people are expected to have skills at making and selling beaten rice and murai or bhuja (roated rice). In social and religious functions in the Rajbanshi society, the Gangais are asked for preparing beaten rice but nowadays machines have almost replaced the system because much more beaten rice can be produced by machines in a short time. This has adversely affected the traditional occupation of the Gangais. Most of the Rajbanshi people prepare beaten rice for their consumption at homes. The delicacy of the beaten rice prepared by them is incomparable with that of mechanical production.

d. Hadi: The Hadi sub-caste is expected to play the band music as their occupation. This traditional occupation still exists in the society. They earn by playing the band music at festivals, marriages, funerals, etc. Thus, the Hadi community is very important in the Rajbanshi society for ritual and ceremonial perspectives.

e. Thakur: In the Rajbanshi society, the Thakurs are known as Hajam, Nau, Napit, etc. They are hairdressers by occupation. Besides cutting hair, Thakurs act as priests at births and deaths. Therefore, the role of Thakurs is still very important inseparable role in the society. It is also the Thakurs who receive guests at social and religious functions in the society. Therefore, the Thakurs are more respected and offered money, clothes and foods with high respect. 
A certain labour system is established in the Rajbanshi family for the widow. However, the labour of the widow has been nearly displaced by industrialization of husking and beating rice. Remarriage is well recognized in the society. Tradition allows them to keep Daguwa, a working husband. If the widow does not marry again to pay homage for her demised husband, she is offered to husk rice by Devaniya, Jamindar, Choudhary, and Patuwari people for wages to make her livelihood. She is paid 7 kattas of rice for husking 1 muri (about $60 \mathrm{~K}$. G.) of rice. A Devaniya family generally needs 30 to 40 muris of rice a year. Thus, the wage is enough for a widow. But nowadays because of the establishment of rice mills, this occupation has almost been displaced. The old Rajbanshi people of the village say that the system was in practice 3-4 decades ago.

\section{CONCLUSION}

Rajbanshi community traditionally practices agriculture and animal husbandry. Their traditional labour practices and labour arrangement system have been evolving mainly around these two activities. Since the process of Indian Marwari and hill people immigration started coming in Jhapa and Morang districts, their traditional practices have been affected. It has further been affected by malaria eradication program, implementation of Land Reform Act 1964, construction of East west High way, communication; their exposure to other context which have changed the traditional practices of the labour systems. However, this short article tries to highlight some of the aspects of Rajbanshi traditional as well as existing labour practices and labour arrangement systems primarily existed in Jhapa district.

\section{REFERENCES}

Dahal, Dilliram. (edt.)(2056 B.S). Nepalko kehi Pichadiyaka Jatiharuko Samajik-Arthik Adhayan. Kathmandu: Nepal ra Asiali Research center

Gautam, R and Prasain, J. N. (2006). Nepal Ma Prachalit Bandha Tatha Badhyakari Shramshambandhaharu (Text in Nepali). Kathmandu: Nepalese Trade Unions Fedration (GEFONT). 
Prasain, J. N. (2007). "Poverty Alleviation and Livelihood Options Rural Nepal". Unpublished Ph.D. Dissertation Submitted to the Dean's Office of Humanities and Social Sciences, T. U, Kirtipur.

Rajbanshi, PholSingh. (2051 B.S). Rajbanshi Bhasa Sahitya Sankriti ar Itihas (Ek Sankalan), Jhapa: Rajbanshi Bhasa Prachar Samiti.

Rajbanshi (koch), Durga ChandraShing. (2057 B.S). Rajbanshi (koch) Jatiko Dharma ra Sankriti. Jhapa: Mrs Tika Devi Rajbanshi.

Shrestha, Soyambhu Lal. (2028 B.S). Hami Nepali. Lalitpur: Shrestha Prakashan

Bengal District Gazetteers. (1947). Bengal District Gazetteers. Darjeeling: Bengal Government Press, Alipore, Bengal.

Caplan, Loinel. (1970/2000). Land and Social Change in East Nepal : A Study of Hindu-Tribal Relation. London: Routledge and Kegan Paul.

Koch Bihar. Gazetter of India, West Bengal (p.56). (Detailed Informatioin not available).

CBS. (2002). Population of Nepal. Central Bureau of Statistic. Nepal: CBS.

Sanyal, C.C. (1967). Rajbanshies of West Bengal, Calcutta: Asiatic Society. 